\title{
Inhibition by $\alpha$-chlorohydrin of fluid reabsorption in the rat cauda epididymidis
}

\author{
P. Y. D. Wong and C. H. Yeung \\ Department of Physiology, Faculty of Medicine, University of Hong Kong, Hong Kong
}

Daily injections of $\alpha$-chlorohydrin (3-chloro-1,2-propanediol) at a dose of 7-8 $\mathrm{mg} / \mathrm{kg}$ produce infertility in male rats (Ericsson, 1970; Ericsson \& Baker, 1970). The mechanism of action of this compound is still unknown but previous studies have indicated that it has at least two sites of action. When given at high doses, $\alpha$-chlorohydrin produces characteristic lesions in the caput epididymidis, leading to an occlusion of the epididymal duct and subsequent degeneration of the germinal epithelium (Ericsson, 1970; Hoffer, Hamilton \& Fawcett, 1973; Cooper, Jones \& Jackson, 1974). At lower doses, there is a functional interference with spermatozoa, causing a reversible phase of sterility (Coppola, 1969; Gunn, Gould \& Anderson, 1969; Vickery, Erickson \& Bennett, 1974), and the metabolism of testicular and epididymal spermatozoa is known to be affected (Mohri, Suter, Brown-Woodman, White \& Ridley, 1975; Edwards, Dacheux \& Waites, 1976).

There is evidence that $\alpha$-chlorohydrin may affect transport processes across the epididymal duct. Reijonen, Kormano \& Ericsson (1975) have shown that the effect of a high dose of $\alpha$-chlorohydrin is dependent on active absorption in the epididymis. Histological and ultrastructural findings also suggested that the effect of $\alpha$-chlorohydrin may be due to an interference with fluid reabsorption (Gunn et al., 1969; Hoffer et al., 1973). We have previously shown that an isolated segment of rat cauda epididymidis actively resorbs fluid. This process is dependent on an active transepithelial transport of sodium ions (Wong \& Yeung, 1977a) and is inhibited by castration, suggesting that it is dependent on the presence of circulating androgens (Wong \& Yeung, 1977b). The cauda epididymidis is believed to be a site of action of $\alpha$-chlorohydrin (Coppola, 1969; Samojlik \& Chang, 1970; Crabo \& Appelgren, 1972) and we therefore studied the effects of low doses of $\alpha$-chlorohydrin on fluid reabsorption in isolated segments of rat cauda epididymidis.

\section{Experiment I}

Male rats of the Sprague-Dawley strain were injected intraperitoneally with $0 \cdot 9,3,9$ or $18 \mathrm{mg}$ $\alpha$-chlorohydrin (99\% pure, mol. wt 110.54$)$. The drug was diluted with $0.9 \%(\mathrm{w} / \mathrm{v}) \mathrm{NaCl}$ solution to the desired concentration, and was injected in $0.06 \mathrm{ml} / 100 \mathrm{~g}$ body weight. The control animals were injected with the same volume of $0.9 \% \mathrm{NaCl}$ solution. After 7 days, the rats were killed and fluid reabsorption was measured in an isolated segment of the cauda epididymidis by the technique previously described (Wong \& Yeung, 1977a). The rate of fluid reabsorption was expressed as $\mu 1$ fluid reabsorbed per $\mathrm{cm}^{2}$ of duct per $30 \mathrm{~min}$. Sections of cauda epididymidis from control and treated $(9 \mathrm{mg} / \mathrm{kg} /$ day) rats were fixed in $10 \%$ formalin and stained with haematoxylin and eosin for examination by light microscopy. There were no histological differences between the tissues from treated and control rats.

The mean ( \pm S.E.M.) rates of fluid reabsorption in rats treated with 0.9 and $3 \mathrm{mg} \alpha$-chlorohydrin/ $\mathrm{kg} /$ day were $2 \cdot 16 \pm 0.14 \mu \mathrm{l} / \mathrm{cm}^{2} / 30 \mathrm{~min}(6 \mathrm{rats})$ and $2.05 \pm 0.07 \mu \mathrm{l} / \mathrm{cm}^{2} / 30 \mathrm{~min}$ (4 rats), respectively. These values were not significantly different from the control rate of $2 \cdot 30 \pm 0.14 \mu \mathrm{l} / \mathrm{cm}^{2} / 30 \mathrm{~min}$ ( 6 rats). However, when 10 rats were treated with $9 \mathrm{mg} / \mathrm{kg} /$ day for 7 days, the fluid reabsorption rate was $1.34 \pm 0.13 \mu \mathrm{l} / \mathrm{cm}^{2} / 30 \mathrm{~min}$, which was significantly different from the control $(P<0.001)$ (Student's $t$ test), and represented a $42 \pm 6 \%$ inhibition. There was no further reduction in 6 rats treated with $18 \mathrm{mg} / \mathrm{kg} /$ day and the rate of fluid reabsorption in the ducts of these animals was $1.30 \pm 0.08 \mu \mathrm{l} / \mathrm{cm}^{2} / \mathrm{min}$. This value is significantly different from that for the control rats $(P<0.001$, Student's $t$ test). The dose rate giving half the maximal inhibition was about $5 \mathrm{mg} / \mathrm{kg} / \mathrm{day}$. 


\section{Experiment II}

Sprague-Dawley rats were similarly treated with $9 \mathrm{mg} \alpha$-chlorohydrin $/ \mathrm{kg} /$ day for 14 days, and as shown in Table 1 the rate of fluid reabsorption in the isolated epididymal duct was not less than that after treatment for only 7 days. The effect on fluid reabsorption was clearly reversible and the reabsorption rate was completely restored within 1 week of cessation of treatment. Ethylene chlorohydrin (Carlo Erba), which has a structure similar to that of $\alpha$-chlorohydrin and is unable to produce sterility in male rats (Ericsson \& Youngdale, 1970), had no effect on fluid reabsorption when injected i.p. into rats for 7 days at a dose rate of $6.4 \mathrm{mg} / \mathrm{kg} /$ day (Table 1).

Table 1. The effect of $\alpha$-chlorohydrin $(9 \mathrm{mg} / \mathrm{kg} / \mathrm{day})$ and ethylene chlorohydrin $(6.5 \mathrm{mg} / \mathrm{kg} /$ day) on fluid reabsorption (expressed as $\mu \mathrm{l} / \mathrm{cm}^{2} / 30 \mathrm{~min}$ ) in isolated segments (no. in parentheses, each from one animal) of rat cauda epididymidis

\begin{tabular}{|c|c|c|c|c|c|}
\hline \multirow[b]{2}{*}{$\begin{array}{l}\text { Intraluminal } \\
\text { fluid }\end{array}$} & \multirow[b]{2}{*}{$\begin{array}{l}\text { No treatment } \\
\text { (control) }\end{array}$} & \multicolumn{3}{|c|}{$\alpha$-Chlorohydrin treatment } & \multirow{2}{*}{$\begin{array}{l}\text { Ethylene } \\
\text { chlorohydrin } \\
\text { treatment } \\
\text { (7 days) }\end{array}$} \\
\hline & & 7 days & 14 days & $\begin{array}{l}7 \text { days ( }+7 \text { days } \\
\text { for recovery) }\end{array}$ & \\
\hline Normal solution & $2 \cdot 30 \pm 0 \cdot 14(6)$ & ${ }^{*} 1.34 \pm 0.13(10)$ & $*_{1} 1.41 \pm 0.19(6)$ & $2 \cdot 14 \pm 0 \cdot 12(6)$ & $2.08 \pm 0.13(5)$ \\
\hline $\mathrm{Na}^{+}$-free solution & $* 1.20+0.18(7)$ & $1 \cdot 12+0.13(5)$ & - & - & - \\
\hline
\end{tabular}

* Significantly different compared with control, normal solution value $(P<0.001$, Student's $t$ test).

The dose of $9 \mathrm{mg} \alpha$-chlorohydrin $/ \mathrm{kg} /$ day which was able to inhibit fluid reabsorption in the cauda epididymidis also produces sterility in male rats (Ericsson \& Baker, 1970; Tsunoda \& Chang, 1976). It seems possible that the primary action of $\alpha$-chlorohydrin is to impair the active transport of sodium and hence fluid reabsorption in the cauda epididymidis. To test this, the effect of $\alpha$-chlorohydrin treatment ( $9 \mathrm{mg} / \mathrm{kg} /$ day for 7 days) on fiuid reabsorption was studied in isolated epididymal ducts in which the intraluminal sodium ions had been replaced by choline. Sodium reabsorption was thereby prevented and, as found previously (Wong \& Yeung, 1977a), the rate of fluid reabsorption was reduced by about $50 \%$ (Table 1 ), leaving unaffected the component of fluid reabsorption which is independent of the presence of sodium ions. $\alpha$-Chlorohydrin may therefore affect only the $\mathrm{Na}^{+}$dependent component of fluid reabsorption in the rat cauda epididymidis.

\section{Experiment III}

The effect of $\alpha$-chlorohydrin on sodium transport across isolated frog skin, another transporting epithelium, was studied. Frogs (Rana temporaria) were divided into 2 groups. Animals in Group 1 were kept in tap water and those in Group 2 were kept in tap water containing $26 \mu \mathrm{g} \alpha$-chlorohydrin/ $\mathrm{ml}$. After killing 24-48 h later, sodium transport across pieces of abdominal skin was measured as described previously (Cuthbert \& Wong, 1972). After $30 \mathrm{~min}$ for equilibration, the short-circuit current was $45 \cdot 8 \pm 5 \cdot 0$ (S.E.M.) $\mu \mathrm{A} / \mathrm{cm}^{2}$ for Group 1 and $22 \cdot 2 \pm 2 \cdot 7 \mu \mathrm{A} / \mathrm{cm}^{2}$ for Group 2 . These means are significantly different $(P<0.002)$ and suggest that $\alpha$-chlorohydrin also inhibits sodium transport across frog skins.

Our experiments have demonstrated an inhibitory and reversible effect of low doses of $\alpha$-chlorohydrin on fluid reabsorption in the rat cauda epididymidis. These results are consistent with those of Gunn et al. (1969) and Ericsson \& Baker (1970), and they indicate that the impairment in fluid reabsorption may not be due to structural damage to the epithelium, but to interference with specific transport mechanisms, particularly that of sodium, in the epididymal duct as well as to the known effects of $\alpha$-chlorohydrin on the biochemistry of the epididymis and spermatozoa.

We thank Dr M. Chulavatnatol for the gift of $\alpha$-chlorohydrin and Professor A. C. L. Hsieh for reading the manuscript. This work was supported by a grant from the World Health Organization. 


\section{References}

COOPER, E.R.A., JoNes, A.R. \& JACKsON, H. (1974) Effect of $\alpha$-chlorohydrin and related compounds on the reproductive organs and fertility of the male rat. J. Reprod. Fert. 38, 379-386.

CoppolA, J.A. (1969) An extragonadal male antifertility agent. Life Sci. 8, 43-48.

CRABO, B. \& APPELGREN, L.E. (1972) Distribution of $\left[{ }^{14} \mathrm{C}\right] \alpha$-chlorohydrin in mice and rats. $J$. Reprod. Fert. 30, 161-163.

Cuthbert, A.W. \& Wong, P.Y.D. (1972) The role of calcium ions in the interaction of amiloride with membrane receptors. Molec. Pharmac. 8, 222-229.

EDWards, E.M., DacheuX, J.L. \& Waites, G.M.H. (1976) Effects of $\alpha$-chlorohydrin on the metabolism of testicular and epididymal spermatozoa of rams. J. Reprod. Fert. 48, 265-270.

ERICsson, R.J. (1970) Male antifertility compounds: U-5897 as a rat chemosterilant. J. Reprod. Fert. 22, 213-222.

ERICsSON, R.J. \& BAKER, V.F. (1970) Male antifertility compounds: biological properties of U-5897 and U-15, 646. J. Reprod. Fert. 21, 267-273.

ERicsson, R.J. \& Youngdale, G.A. (1970) Male antifertility compounds: structure and activity relationships of U-5897, U-15,656 and related substances. J. Reprod. Fert. 21, 263-266.

GunN, S.A., Gould, T.C. \& ANDerson, W.A.D. (1969) Possible mechanism of post-testicular antifertility action of 3-chloro-1,2-propanediol. Proc. Soc. exp. Biol. Med. 132, 656-659.
Hoffer, A.P., Hamlton, D.W. \& Fawcett, D.W. (1973) The ultrastructural pathology of the rat epididymis after administration of $\alpha$-chlorohydrin (U-5897). 1. Effects of a single high dose. Anat. Rec. 175, 203-230.

MOHRI, H., Suter, D.A.I., Brown-WoOdman, P.D.C., WhITe, I.G. \& RidLeX, D.D. (1975) Identification of the biochemical lesion produced by $\alpha$-chlorohydrin in spermatozoa. Nature, Lond. 255, 75-77.

Reijonen, K., Kormano, M. \& Ericsson, R.J. (1975) Studies on the rat epididymal blood vessels following alpha-chlorohydrin administration. Biol. Reprod. 12, 483-490.

Samojlik, E. \& Chang, M.C. (1970) Antifertility activity of 3-chloro-1,2-propanediol (U-5897) on rats. Biol. Reprod. 2, 299-304.

Tsunoda, Y. \& Chang, M.C. (1976) Fertilizing ability in vivo and in vitro of spermatozoa of rats and mice treated with $\alpha$-chlorohydrin. J. Reprod. Fert. 46, $401-406$.

ViCKery, B.H., ERICKSON, G.L. \& BenNeTT, J.P. (1974) Mechanism of antifertility action of low doses of $\alpha$-chlorohydrin in the male rat. $J$. Reprod. Fert. 38, 1-10.

Wong, P.Y.D. \& Yeung, C.H. (1977a) Fluid reabsorption in the isolated duct of rat cauda epididymidis. J. Reprod. Fert. 49, 77-81.

Wong, P.Y.D. \& Yeung, C.H. (1977b) Hormonal dependence of fluid reabsorption in isolated rat cauda epididymis in vitro. $J$. Endocr. $72,12 P-13 P$.

Received 24 March 1977 